\title{
$\boldsymbol{\nabla}$ Artikkeli
}

\section{Väkivallan sukupuoli iltapäivälehdissä}

\begin{abstract}
Artikkelissa tarkastellaan suomalaisten iltapäivälehtien väkivaltarikosuutisointia kysyen, millä tavoin siinä näkyy ja tuottuu väkivallan tekijöiden ja uhrien sukupuoli. Aineistona ovat vuonna 2009 Iltalehdessä ja Ilta-Sanomissa ilmestyneet naisten ja miesten tekemästä väkivallasta kertovat rikosuutisartikkelit ja niiden otsikot. Lähtökohtana on konstruktionistinen näkemys rikosuutisissa tuotettujen esitysten, kulttuurisen tiedon ja todellisuuden yhteen kietoutumisesta. Rikosuutisointia lähestytään uutisarvon käsitettä hyödyntäen ja pohditaan, millaista sukupuolten ja väkivallan välistä suhteutumista uutisoinnissa rakennetaan. Otsikoiden analyysissa keskitytään siihen, millä lailla väkivallan tekijöiden ja uhrien sukupuolet ovat niissä esillä. Naisten sukupuoli niin väkivallan tekijöinä kuin uhreina on uutisoinnissa korostuneemmin esillä kuin miesten. Miesten ja naisten erilainen suhteutuminen väkivaltaan jäsentää uutisointia moniulotteisesti ja osin paradoksaalisilla mutta sukupuolistunutta sosiaalista järjestystä ylläpitävillä tavoilla.
\end{abstract}

AVAINSANAT: väkivalta, sukupuoli, uutisarvo, rikosuutisointi

$\mathrm{V}$ äkivalta on iltapäivälehtien jokapäiväinen uutisoinnin aihe. Iltapäivälehtien tyyliin kuuluu siitä kertominen sensaatiomaisesti, poikkeuksellisia tapauksia korostaen'. 2000-Iuvun alussa esiin tuotu huoli median väkivaltaistumisesta poiki tutkimuksia, joissa väkivaltauutisoinnin määrän ja järkyttävyyden todettiin nousseen iltapäivälehtien etusivuilla ja lööpeissä (Kivivuori ym. 2002; Smolej 2011; Syrjälä 2007). Näissä tarkasteluissa ei kuitenkaan keskitytty uutisoidun väkivallan tekijöiden ja uhrien sukupuoleen. Sukupuolta väkivaltauutisoinnissa on ylipäänsä tutkittu Suomessa niukalti (ks. kuitenkin Kantola ym. 2011; Mäkelä 2002; Nikunen 2005). Viime vuosina kasvanut kiinnostus naisten tekemää väkivaltaa kohtaan niin tutkimuksessa kuin mediassa tekee väkivallan sukupuolen tarkastelusta entistä ajankohtaisempaa.

Käsittelen artikkelissani iltapäivälehtien rikosuutisointia väkivaltaa ja sukupuolta koskevien käsitysten tuottamisen kannalta. Analysoin iltapäivälehtien rikosuutisten otsikoita vuodelta 2009. Keskityn erityisesti siihen, miten väkivallan tekijöiden sukupuolesta kerrotaan ${ }^{2}$. Tarkasteluani ohjaa konstruktionistinen ymmärrys todellisuuden ja tiedon sosiaalisesta muotoutumisesta sekä feministinen käsitys sukupuolesta paitsi sosiaalisen elämän myös väkivallan tekemisen ja kokemisen keskeisenä jäsentäjänä. 
Näkökulmani sukupuoleen pohjautuu etnometodologiseen ymmärrykseen sekä esimerkiksi Theresa de Lauretiksen (1987) ajatuksiin sukupuolesta sosiaalisesti ja historiallisesti rakentuneena konstruktiona, joka on sidoksissa jatkuvaan (re)presentointiprosessiinsa.

Lähestyn uutisointia sekä laajemman kulttuurisen kontekstin että uutistekstien tuottamista säätelevien käytäntöjen ja periaatteiden, kuten uutisarvon maksimoimisen, muovaamana. Pyrin osoittamaan, kuinka sukupuoliin liitetyt kulttuuriset käsitykset ohjaavat toimittajien tekemiä valintoja rikosuutisoinnissa ja kuinka sukupuolta toisaalta tämän myötä tuotetaan. Tarkastelussani risteävät mediatutkimuksellinen, feministinen ja kriminologinen näkökulma, joiden välille pyrin rakentamaan dialogia sosiaalis-psykologisista, eli sosiaalisen ja yksilöllisen linkittävistä, taustaolettamuksista käsin. Avaan seuraavaksi hieman tarkemmin teoreettisia lähtökohtiani.

\section{Kulttuurinen tieto, representaatioprosessit ja todellisuus}

Teoreettinen kehykseni pohjautuu ensisijaisesti kulttuurintutkimukselliselle näkökulmalle, jonka mukaan ilmiöitä ja asioita ei voida erottaa niitä koskevasta sosiaalisesti tuotetusta tiedosta (Hall 1997, 33-39). Todellisuutta muodostetaan representaatioiden kautta, joiden myötä ilmiöt ja asiat saavat tiettyjä merkityksiä. Maailmaa toisin sanoin merkityksellistetään representaatioprosesseissa. Merkityksellistäminen on sidoksissa kulttuuriseen kontekstiin, jota se myös rakentaa ja ylläpitää (emt.). Tarkemmin ilmaistuna se edellyttää kulttuuriksi kutsuttua jaettua, arvojärjestelmiin linkittyvää tietämystä, joka representaatioprosesseissa kiinnittyy tietämisen kohteisiin, maailmaan ja sen ilmiöihin.

Kulttuurintutkimuksellisen näkökulman ohella tarkasteluani ohjaa etnometodologisen lähestymistavan inspiroima kiinnostus arkitietämyksen ja sen säännönalaisuuksien muodostumiseen. Etnometodologinen näkökulma painottaa ihmisten arkista, tilannesidonnaista kanssakäymistä, jossa muodostetaan sosiaalista järjestystä ja siihen liittyvää arkitietoa (Garfinkel 1984 [1967]). Feministinen etnometodologia keskittyy sukupuolen merkitykseen sosiaalisen järjestyksen muotoutumisessa. Candace Westin ja Don Zimmermanin (1987) mukaan kulttuurissa vallitsee aina tiettyjä normatiivisia käsityksiä, jotka määrittelevät naiset ja miehet tietynlaisiksi ja joiden pohjalta jako sukupuolikategorioihin tehdään. Näiden käsitysten mukainen miesten ja naisten toiminta ja ominaisuudet nähdään luonnollisina ja normaaleina.

Minna Nikunen (2005) on tarkastellut feministisestä etnometodologisesta näkökulmasta murha-itsemurhien uutisointia tilanteisina käytäntöinä, jotka pohjautuvat kulttuurisiin, sukupuolistuneisiin kategorisointeihin ja niissä muodostuviin moraalisiin järjestyksiin. Nikusen (2006) mukaan väkivaltaisesta toiminnasta tehdään uutisoinnissa ymmärrettävää hyödyntämällä arkitietoon liittyviä sukupuolikategorioita ja niihin liittyviä käsityksiä. Sukupuolia koskevat käsitykset toisin sanoin vaikuttavat siihen, kuinka väkivalta nähdään ja esitetään mediassa. Väkivallasta tehdyillä sukupuolistuneilla tulkinnoilla on merkittäviä ja konkreettisia seurauksia, sillä ne muovaavat 
käsitysten lisäksi esimerkiksi väkivaltaan kohdistettuja toimenpiteitä (emt.). Samanaikaisesti sukupuolistunut tulkinta (tai merkityksellistäminen) pitää yllä sukupuolta eroina ja valtasuhteena.

Printtimedian rikosuutisissa sukupuolen ja väkivallan merkityksellistäminen tapahtuu suurelta osin kielenkäytössä, jonka analyysiin tutkimuksessani keskityn. Kieli on yleensäkin keskeinen, vaikkei suinkaan ainoa representaatiojärjestelmä (Halliday 1978). Tekstit, joita kieltä käyttäen muodostetaan, rakentuvat kielen käyttäjien tekemistä valinnoista sekä kulttuurisen että tilanteisen kontekstin puitteissa (emt., 126). Foucault'laisen (esim. Foucault 1972, 185-186) näkökulman mukaan tietyllä tavalla kieltä käyttäen todellisuudesta tuotettu ja sitä tuottava tieto limittyy aina valtaan. Kun tietoa tuotetaan ja hallitaan valta-asemasta käsin, voidaan puhua ideologisuudesta. Esimerkiksi mediatekstien voidaan katsoa olevan ideologisia silloin, kun ne kierrättävät itsestäänselvyyksinä pidettyjä, kyseenalaistamattomina totuuksina näyttäytyviä tulkintoja (Fairclough 1997, 64). Totaalista ideologisuutta tuskin kuitenkaan minkään tahon näkemys voi saavuttaa, koska jo itsessään ristiriitaisuuksia ja monimerkityksellisyyttä sisältäviä tulkintoja on aina mahdollista haastaa ja uudistaa (Foucault 1976, 100-102).

Konstruktionistisesta näkökulmasta tietoa siis tuotetaan aina tulkintojen kautta. Jotta ymmärtäisimme mediatekstien representaatioprosesseissaan tuottaman tiedon luonnetta, on huomioitava niiden tuottamista ohjaavat periaatteet ja arvot. Anna Mäkelä ym. $(2006,8)$ ovat todenneet, että sosiaalitieteissä mediatekstejä on lähestytty usein todellisuutta heijastavina tai sen kanssa vastakkain asetettuina. Tällöin mediarepresentaatiot voivat näyttäytyä vääristynyttä tietoa antavina ja ulkoisesta todellisuudesta irrallisina. Jos näemme kaiken tiedon sosiaalisesti rakentuvana, ei tällainen tutkimusasetelma ole mielekäs. Esimerkiksi väkivaltaa tarkasteltaessa rikosuhritilastojenkaan ei voida katsoa kertovan absoluuttisia faktoja todellisuudesta, koska niidenkin piirtämään kuvaan vaikuttavat tutkijoiden omasta näkökulmastaan käsin tekemät valinnat ja tulkinnat (Ronkainen 2004). Hedelmällisempää on lähestyä mediarepresentaatioita kulttuurisina käytäntöinä, jotka tuottavat todellisuuttamme muovaavaa tietoa omanlaisistaan lähtökohdistaan käsin. Näin ollen vaikka tutkimuksessani kiinnitän huomiota väkivaltauutisoinnin ja rikostilastojen eroihin, en oleta kumpienkaan mahdollistamien tulkintojen kykenevän aukottomasti kertomaan väkivallan todellisuudesta, vaan olevan sidoksissa tiettyihin, osittain toisistaan poikkeaviin arvoihin ja konventioihin. En myöskään lähesty tässä tutkimuksessa sukupuolta ensisijaisesti uutisointia edeltävänä, esimerkiksi toimittajien uutisoinnin tyyliin vaikuttavana muuttujana, vaan mediateksteissä tuottuvana ja niissä merkityksellistyvänä.

\section{Uutisarvo, väkivalta ja sukupuoli}

Mediatekstit syntyvät kulttuuris-historiallisesti saatavilla olevien merkityssysteemien ja media-alan käytäntöjen, kuten lajityyppien ja totuttujen kehystämistapojen, yhteisvaikutuksen alaisina (Erickson ym. 1987). Kertomukset, joita mediateksteissä tuotetaan, ovat sidoksissa menneisyyteen, jo kerrottuun ja sanottuun (Valtonen 1998, 118). 
Lehtien toimitusten työmenetelmällisten normien lisäksi rikosten uutisointiin vaikuttaa poliisin ja tuomioistuinten halukkuus julkistaa tietoja rikostapauksista (Hemánus 1966, 36-37, 252). Se, kuinka uutisarvoisena kutakin väkivaltatapausta pidetään, määrittää keskeisesti tapausten valikoitumista uutisoitaviksi ja sitä, miten niistä uutisoidaan. Kulttuurisista normeista voimakkaimmin poikkeavat ja järkyttävimmät tapaukset ovat yleensä uutisarvoisimpia. Siten ne saavat myös eniten mediahuomiota osakseen. (Jewkes 2004, 108-109.) Toisaalta esimerkiksi henkirikosten on todettu valikoituvan uutisointiin myös sen perusteella, kuinka hyvin ne ovat sovitettavissa vallitseviin käsityksiin esimerkiksi rodusta ja sukupuolesta (Gruenewald ym. 2009). Poikkeuksellisuuden lisäksi uutisointia ohjaa siis myös tuttuus, tapausten tulee olla lukijoille tunnistettavia.

Väkivallan sukupuolistuneisuuden vuoksi naisten tekemä väkivalta nähdään yleensä yllättävämpänä ja täten uutisarvoisempana kuin miesten tekemä (Berrington \& Honkatukia 2002). Onkin todettu, että naisten tekemää väkivaltaa esitetään rikosuutisissa korostuneemmin kuin miesten (esim. Naylor 2001). Sukupuolistereotypioita mukaillen naisten tekemää väkivaltaa esitetään myös laadultaan irrationaalisempana ja poikkeuksellisempana kuin miesten (emt.). Yvonne Jewkesin (2004, 40; ks. myös Kivivuori ym. 2002) mukaan väkivaltauutisoinnissa esiintyy myös uhreina enemmän naisia kuin miehiä. Naisiin kohdistuva väkivalta on uutisarvoista erityisesti silloin, kun se on seksuaalista, uhrin kuolemaan johtavaa, kun tekijä on uhrille tuntematon mies ja kun se tapahtuu julkisella paikalla (Carter 1998). Naisiin kohdistuvasta parisuhdeväkivallasta puolestaan uutisoidaan yleensä niukkasanaisesti ja ainoastaan erityisen poikkeuksellisiin tapauksiin keskittyen (Meloy \& Miller 2009; myös Nikunen 2011). Myös miesten toisiin miehiin kohdistamasta väkivallasta uutisoidaan usein suppeasti ja rutiininomaisesti, suomalaisessa kontekstissa varsinkin silloin, kun se liitetään alkoholiin ja nähdään tämän myötä väkivallan ns. perustyyppiä vastaavana (Nikunen 2005, 229)33.

Iltapäivälehdet Ilta- Sanomat ja Iltalehti lukeutuvat kummatkin Suomessa eniten luettuihin sanomalehtiin (Levikintarkastus 2012)4. Mullistukset mediamarkkinoilla 2000-luvulla ja erityisesti internetin kasvanut merkitys (Väliverronen 2009) ovat kuitenkin kiristäneet eri medioiden välistä kilpailua, minkä vuoksi paineet maksimoida uutisarvoisuus ovat entistä kovemmat. Iltapäivälehdissä väkivallan järkyttävyyttä ja yllättävyyttä on 2000-luvulla alettu korostaa tuomalla se lähemmäs "tavallisten" ihmisten arkielämää, jolloin myös parisuhdeväkivallan ja lapsiin kohdistuvan väkivallan kuvaukset ovat lisääntyneet (Syrjälä 2007). Leena Mäkipää ja Tuomo Mörä (2009) ovat todenneet, että tultaessa 1980-luvulta 2000-luvulle Ilta-Sanomien henkirikosuutisissa yleistyivät myös tekijöiden ja uhrien luonnekuvaukset ja tekojen yhteisöllisen ja moraalisen merkityksen painottaminen, joiden myötä uutisoinnin rooli moraalisen järjestyksen rakentajana on korostunut.

Väkivaltatapausten uutisarvoisimpina nähdyt elementit tuodaan yleensä esiin rikosuutisjuttujen otsikoissa, joiden funktio on myydä juttu lukijoille. Otsikot rakennetaan sen oletuksen varaan, että lukijoilla on kulttuurista tietoa, jota hyödyntämällä he voivat tehdä tulkinnan kerrotuista tapahtumista pelkistetynkin kuvauksen varassa (Nikunen 2005, 81-82). Otsikoille varattu tila on aina myös rajallinen, minkä vuoksi 
niihin sisällytetyillä seikoilla on todennäköisesti katsottu olevan erityistä painoarvoa. Tämän ansiosta niiden analyysi valottaa keskeisesti sitä, mikä toistuu kulttuurisesti itsestään selvänä ja mikä poikkeavana.

\section{Sukupuoli iltapäivälehtien väkivaltarikosuutisoinnissa vuonna 2009}

Tarkastelen seuraavaksi vuoden 2009 väkivaltarikosuutisointia kokonaisuudessaan, minkä jälkeen siirryn uutisjuttujen otsikoiden analyysiin. Aineisto koostuu vuonna 2009 Ilta- Sanomissa ja Iltalehdessä ilmestyneistä, Suomessa tapahtunutta väkivaltaa käsittelevistä rikosuutisjutuista. Se on kerätty mikrofilmien avulla. Väkivalta, jota käsittelevät jutut on sisällytetty aineistoon, määrittyy toisen ihmisen pääasiassa fyysiseksi tahalliseksi vahingoittamiseksi, sen yrittämiseksi tai sen pelkoa aiheuttavaksi toiminnaksi identifioitavissa olevan henkilön taholta. Olen ottanut aineistoon ainoastaan jutut, joissa mainitaan (joko otsikossa tai leipätekstissä) väkivallan tekijä (tai epäilty henkilö) ja hänen sukupuolensa sekä henkilö(t), joihin väkivalta kohdistuu. Rikosnimikkeittäin kyse on pääasiallisesti pahoinpitelyistä, henkirikoksista, seksuaalisesta hyväksikäytöstä ja raiskauksista. Tarkastelun ulkopuolelle ovat jääneet esimerkiksi pakottaminen, seksuaalinen ahdistelu, paritus, vapauden riisto ja ryöstöt, joiden määrittely väkivaltarikoksiksi ei ole aineistossa yhtä selvärajaista kuin edellä mainittujen tekoluokkien kohdalla. Näiden rajausten vuoksi valittu aineisto ei anna kokonaiskuvaa lehdissä esiintyneestä väkivallasta. Se antaa kuitenkin keskeisiä suuntaviivoja siitä, millä tavoin naisten ja miesten tekemästä väkivallasta uutisoidaan. Aineistoon sisällytettäviä juttuja oli Ilta-Sanomissa 421 ja Iltalehdessä 509, eli yhteensä $930^{5} .732$ jutussa (79 \%) kerrotaan miesten ja 159 (17\%) naisten tekemästä väkivallasta. Naisten ja miesten yhdessä tekemästä väkivallasta kerrotaan 45 jutussa $(5 \%)^{6}$.

Oheiseen taulukkoon on eritelty jutuissa esiintyvä väkivalta tekijöiden ja uhrien mukaan. Osassa jutuista kerrotaan useaan eri uhri- tai tekijäkategoriaan sijoittuvasta väkivallasta, jolloin sama juttu on merkattu useaan eri kategoriaan. Yhdessä jutussa ilmenevä, samaan kategoriaan sijoittuva väkivalta on merkattu vain kerran, vaikka uhreja olisi useita. Lapsiin kohdistuvaksi olen luokitellut väkivallan, jonka uhri on alle 18 -vuotias.

Taulukko 1: Rikosuutisjutuissa ilmenevä väkivalta sukupuolittain.

\begin{tabular}{|l|l|l|l|l|}
\hline Tekijä(t): & Miehet (N) & Naiset (N) & Naisia ja miehiä (N) & Yhteensä (N) \\
\hline Mies uhrina & $29 \%(215)$ & $37 \%(64)$ & $24 \%(12)$ & $30 \%(291)$ \\
\hline Nainen uhrina & $36 \%(269)$ & $43 \%(74)$ & $20 \%(10)$ & $37 \%(353)$ \\
\hline Lapsi uhrina (tyttö) & $9 \%(64)$ & $4 \%(7)$ & $18 \%(9)$ & $8 \%(80)$ \\
\hline Lapsi uhrina (poika) & $8 \%(62)$ & $10 \%(18)$ & $14 \%(7)$ & $9 \%(87)$ \\
\hline Mies ja nainen uhrina & $12 \%(92)$ & $1 \%(2)$ & $10 \%(5)$ & $10 \%(99)$ \\
\hline Ei uhrin sukupuolta & $5 \%(38)$ & $4 \%(7)$ & $12 \%(6)$ & $5 \%(51)$ \\
\hline Yhteensä & $77 \%(740)$ & $18 \%(172)$ & $5 \%(49)$ & $100 \%(961)$ \\
\hline
\end{tabular}


Jos naisten ja miesten yhdessä tekemää väkivaltaa ei oteta huomioon, tekijänä esiintyy nainen yhteensä 18 \%:ssa taulukkoon eritellystä väkivallasta. Rikostilastoissa vuonna 2009 naisia väkivallan tekijöistä on noin 14-18 \% (Sipilä \& Honkatukia 2010), eli naisten esittäminen ei lukumääräisesti poikkea paljon tilastoista. Naisten osuus uhreista (37\%) on hieman suurempi kuin miesten (30 \%). Rikostilastoissa puolestaan naiset ja miehet ovat lähes yhtä usein väkivallan uhreina (emt.). Tilastojen valossa vaikuttaakin siltä, että uutisoinnissa on hieman painotettu tapauksia, joissa uhrina on nainen. On kuitenkin muistettava, etteivät laskemani lukumäärät ole suinkaan suoraviivaisesti verrattavissa rikostilastoihin, joissa rikokset on, toisin kuin omassa tarkastelussani, eritelty tapauksittain. Kuten aikaisemmin totesin, rikostilastotkaan eivät suinkaan kata kaikkea tapahtuvaa väkivaltaa tai kerro tulkinnasta vapaata totuutta väkivallasta. Rikostilastojen ulkopuolelle on esimerkiksi katsottu usein jäävän suurelta osin naisten tyypillisimmin kokema läheisissä ihmissuhteissa tapahtuva väkivalta (emt.). Rikostilastojen ja uutisoinnin painotusten välinen ero vihjaa kuitenkin tendensseistä toimittajien tekemissä valinnoissa. Rikosuutisissa kerrotaan poliisin tietoon tulleesta väkivallasta, jonka voi katsoa todennäköisesti sisältyvän rikostilastoihin. Tilastojen ja uutisoinnin vertaaminen näin ollen auttaa osaltaan hahmottamaan uutisarvon muodostumisen säännönalaisuuksia, eli sitä, millaisia tapauksia pidetään korostuneimmin uutisoinnin arvoisina.

Tarkasteltaessa väkivallan eri tyyppien jakaantumista sukupuolittain tulevat uutisoinnin painotukset näkyviin yhä selkeämmin. Olen jaotellut jutuissa ilmenevän väkivallan karkeasti kolmeen luokkaan: muu väkivalta, henkirikokset (kuolemaan johtaneet) ja seksuaalinen väkivalta. Naisten tekijyys on korostunutta erityisesti henkirikosten kohdalla. Niistä kerrotaan yhteensä 395 kertaa, joista 24 \%:ssa tekijänä on nainen. Rikostilastoissa henkirikoksista epäillyistä on naisia 18 \% (Sipilä \& Honkatukia 2010). Muusta väkivallasta kerrotaan 378 kertaa ja seksuaalisesta väkivallasta 122 kertaa. Niiden kummankaan kohdalla naisten osuus tekijöistä ei ole erityisen poikkeava suhteessa rikostilastoihin ( $18 \%$ ja vastaavasti $3 \%$ ). Myös naisten uhrius on korostuneesti esillä henkirikosten kohdalla. Uhrina on nainen $53 \%$ :ssa kokonaismäärästä $(\mathrm{N}=308)$, kun taas rikostilastoissa naisia uhreista on yleensä 10-30 \% (emt.) ${ }^{8}$.

\section{Sukupuolen näkyminen ja näkymättömyys väkivaltatapahtumaa käsittelevissä otsikoissa}

Otsikoiden analyysissa ovat mukana ne otsikot, jotka käsittelevät väkivaltatapahtumaa, siihen suoraan liittyviä seikkoja tai sen välittömiä seurauksiaª. Analyysiin ei ole näin ollen sisällytetty esimerkiksi otsikoita, jotka käsittelevät rikostutkintaa tai oikeudenkäynnin etenemistä, koska tällöin kerronta ei enää kohdistu ensisijaisesti väkivaltatapahtuman ja sen osapuolten ymmärrettäväksi tekemiseen. Tekemääni analyysia voi kuvailla lähtökohdiltaan kriittiseksi tekstianalyysiksi. Se ei kiinnity mihinkään yksittäiseen ja selvärajaiseen menetelmään vaan on luonnehdittavissa lähestymistavaksi, joka pohjautuu kuvaamiini teoreettisiin näkökulmiin. Feministisen diskurs- 
sianalyysin (esim. Lazar 2005) ja faircloughlaisen kriittisen diskurssianalyysin (Fairclough 1997) periaatteita mukaillen kiinnostukseni kohteena on kieltä käytettäessä tehtyjen valintojen merkitys ja yhteys sukupuolten välisten erojen ja valtasuhteiden uusintamiseen. Tähän liittyvä toinen keskeinen lähtökohtani on sukupuolta koskevien itsestäänselvyyksien outouttaminen, mikä tarkoittaa kriittistä kulttuurisen tiedon etäännyttämistä ja reflektointia (van Zoonen 1994).

Olen kiinnittänyt analyysissa erityisesti huomiota siihen, milloin väkivallan tekijän ja uhrin sukupuoli käy otsikosta eksplisiittisesti ilmi ja milloin ei. Tämän lisäksi olen kiinnostunut siitä, kuvataanko väkivaltaista toimintaa kieliopillisesti aktiivi- vai passiivimuodossa tai onko tekijän ja toiminnan välinen yhteys muulla tavoin hämärtynyt. Aikaisemmissa tutkimuksissa on todettu, että esimerkiksi miesten tekemää parisuhdeväkivaltaa kuvataan useammin passiivissa kuin naisten (Frazer \& Miller 2009). Tämän on katsottu vaikuttavan lukijoiden tulkintoihin siten, että passiivin käytön myötä tekijälle asettuu vähemmän vastuuta, uhrille koituneet seuraukset nähdään lievempinä ja väkivalta vähemmän tuomittavana (emt.). Olen tulkinnut myös otsikoiden luomaa kokonaiskuvaa ja sitä, minkä aspektien ympärille niiden uutisarvoisuus näyttää rakentuvan, eli mitä asioita niissä on tuotu esille kiinnostuksen herättämiseksi ja millaisia mielikuvia väkivallasta ja sen osapuolista niissä tämän myötä herätetään. Oheinen taulukko vetää yhteen tekijöiden ja uhrien sukupuolen näkymisen sekä aktiivimuodon yleisyyden eri konteksteihin sijoittuvasta väkivallasta kertovissa otsikoissa.

Taulukko 2: Väkivallan tekijöiden ja uhrien sukupuolen ja aktiivimuodon esiintyminen tekoa kuvaavissa otsikoissa.

\begin{tabular}{|l|l|l|l|l|l|l|}
\hline & $\begin{array}{l}\text { Tekijän } \\
\text { sukupuoli } \\
\text { esillä (N) }\end{array}$ & $\begin{array}{l}\text { Uhrin } \\
\text { sukupuoli } \\
\text { esillä (N) }\end{array}$ & $\begin{array}{l}\text { Teko } \\
\text { aktiivissa } \\
(\mathrm{N})\end{array}$ & $\begin{array}{l}\text { Tekijän } \\
\text { sukupuoli } \\
\text { esillä (N) }\end{array}$ & $\begin{array}{l}\text { Uhrin } \\
\text { sukupuoli } \\
\text { esillä (N) }\end{array}$ & $\begin{array}{l}\text { Teko } \\
\text { aktiivissa } \\
(\mathrm{N})\end{array}$ \\
\hline & Miehet & & & Naiset & & \\
\hline Uhri: puoliso & & & & & & \\
\hline Muu väkivalta & $50 \%(22)$ & $64 \%(22)$ & $50 \%(22)$ & $100 \%(4)$ & $75 \%(4)$ & $100 \%(4)$ \\
\hline Henkirikos & $27 \%(33)$ & $52 \%(33)$ & $18 \%(33)$ & $50 \%(14)$ & $43 \%(14)$ & $21 \%(14)$ \\
\hline Lapsi & & & & & & \\
\hline Muu väkivalta & $55 \%(49)$ & $41 \%(49)$ & $78 \%(49)$ & $73 \%(11)$ & $27 \%(11)$ & $82 \%(11)$ \\
\hline Henkirikos & $40 \%(5)$ & $20 \%(5)$ & $0 \%(5)$ & $40 \%(5)$ & $0 \%(5)$ & $0 \%(5)$ \\
\hline Seksuaalinen & $11 \%(19)$ & $32 \%(19)$ & $16 \%(19)$ & & & \\
\hline Muu nainen & & & & & & \\
\hline Muu väkivalta & $16 \%(32)$ & $22 \%(32)$ & $34 \%(32)$ & $50 \%(16)$ & $50 \%(16)$ & $50 \%(16)$ \\
\hline Henkirikos & $15 \%(27)$ & $52 \%(27)$ & $22 \%(27)$ & $16 \%(19)$ & $16 \%(19)$ & $16 \%(19)$ \\
\hline Seksuaalinen & $13 \%(30)$ & $27 \%(30)$ & $37 \%(30)$ & $100 \%(1)$ & $0 \%(1)$ & $0 \%(1)$ \\
\hline Muu mies & & & & & & \\
\hline Muu väkivalta & $14 \%(134)$ & $20 \%(134)$ & $35 \%(134)$ & $100 \%(1)$ & $0 \%(1)$ & $100 \%(1)$ \\
\hline Henkirikos & $18 \%(40)$ & $28 \%(40)$ & $23 \%(40)$ & $50 \%(2)$ & $0 \%(2)$ & $50 \%(2)$ \\
\hline Seksuaalinen & $100 \%(1)$ & $100 \%(1)$ & $100 \%(1)$ & & & \\
\hline Yhteensä & $23 \%(392)$ & $32 \%(392)$ & $37 \%(392)$ & $48 \%(73)$ & $32 \%(73)$ & $40 \%(73)$ \\
\hline
\end{tabular}


Kuten taulukosta 2 näkyy, väkivallan tekijän sukupuoli on suhteellisesti huomattavasti useammin esillä otsikoissa naisen ollessa tekijänä (48 \%) kuin silloin, kun tekijänä on mies ( $23 \%$ ). Kun puolisoihin (jotka ovat yhtä otsikkoa lukuun ottamatta vastakkaista sukupuolta) kohdistetusta väkivallasta kertovat otsikot lasketaan mukaan, käy ilmi, että naisten sukupuoli uhreina on myös useammin otsikoissa esillä (71/180 eli $39 \%$ ) kuin miesten (48/196 eli $24 \%$ ). Teon kuvaus on aktiivimuodossa hieman useammin tekijöiden ollessa naisia (40 \% vs. miehet $37 \%$ ), mutta tämä vaihtelee kuitenkin konteksteittain. Käsittelen seuraavaksi yksityiskohtaisemmin sitä, miten sukupuoli näkyy väkivallasta kertovien otsikkojen keskeisimmissä konteksteissa: perheissä, sukupuolten sisällä ja perheiden ulkopuolella.

\section{Väkivalta perheissä - sukupuoli kerronnan keskiössä}

Väkivallan tekijöiden sukupuoli on aineistossa näkyvimmin esillä puolisoon tai omiin lapsiin kohdistuvasta väkivallasta kertovissa otsikoissa. Näiden otsikoiden uutisarvoisuus vaikuttaa perustuvan usein osapuolten intiimille suhteelle ja sen kontekstiin sijoitetun väkivallan yllättävyydelle ja traagisuudelle. Puolisoon kohdistuvasta väkivallasta kerrottaessa osapuolet nimetään usein heidän välisen suhteen esiin tuoden "vaimoksi" ja "mieheksi"10, kuten otsikoissa "Nuori avovaimo puukotti miehensä" (IL 20.4.09) ja "Mies hakkasi vaimoaan päiviä" (IL 29.6.09). Naisten sukupuoli väkivallan tekijöinä on kuitenkin (suhteellisesti) useammin ( $61 \%, N=18$ vs. miehet $38 \%, N=55$ ) ja keskeisemmin otsikoissa esillä kuin miesten. Naisten tekemästä väkivallasta kertovat otsikot ovat useammin perusmuotoisia, ainoastaan osapuolet ja väkivaltateon esiin tuovia: "Nainen puukotti miestään" (IL 15.4.09). Kun tekijänä on mies, tuodaan puolestaan useammin esiin väkivaltaan liittyviä yksityiskohtia. Lisäarvoa otsikoihin on haettu esimerkiksi kuvaamalla tekotapaa tai -välinettä: "Mies pahoinpiteli naisen saappailla" (IL 5.1.09). Tämä tukee näkemystä, että naisten tekemänä puolisoon kohdistuva väkivalta voi olla useammin uutinen jo itsessään, kun taas miesten tekemänä sen uutisoiminen voi edellyttää erityisiä mielenkiintoa vangitsevia elementtejä.

Myös aktiivimuoto on hieman yleisempi naisten tekemästä parisuhdeväkivallasta kerrottaessa ( $39 \%, \mathrm{~N}=18$ vs. miehet $33 \%, \mathrm{~N}=55$ ). Saman havainnon tekivät Frazer ja Miller (2009) tutkimuksessaan. Miesten tekemistä henkirikoksista kerrottaessa puolestaan tekijä ei välttämättä esiinny lainkaan, vaan otsikot ovat usein passiivimuodossa. Esimerkiksi otsikossa "Nainen ammuttiin" (IL 11.4.09) uutisoinnin aiheena on ainoastaan se, mitä uhrille on tapahtunut. Kiinnostus ei siis kohdistu väkivallan tekijään. Myös Minna Nikusen $(2005,96)$ tutkimissa vaimonsurma-itsemurhauutisten otsikoissa passiivia esiintyi usein. Nikunen (emt.) on kuvannut, kuinka passiivin käytön myötä väkivalta näyttäytyy pariskunnan yhdessä kohtaamana tragediana, jonka tekijää ja uhria ei aseteta eri tavoin suhteessa väkivaltaan. Tällöin myöskään vastuu väkivallasta ei asetu yksistään, tai lainkaan, tekijälle.

Passiivimuotoisissa otsikoissa uhrin sukupuoli on tärkeämmällä sijalla kuin tekijän. Naisuhrien kohtalon järkyttävyyttä korostetaan ajoittain tuomalla esiin uhrin nuori 
ikä ja/tai äitiys, jonka myötä lasten kohtalo tulee osaksi kerrontaa: "Nuori äiti löytyi kuolleena" (IL 15.9.09). Kun tätä otsikkoa verrataan otsikkoon, joka tuo esiin naispuolison surmaaman miehen isyyden, käy ilmi, millä tavalla sukupuoli vaikuttaa tekijöiden ja uhrien - ja heidän toimintansa ja vastuunsa - painottumiseen. Otsikossa "Nuori naisystävä tappoi perheenisän" (IS 20.4.09) tekijänä ollut nainen asemoidaan (hieman harhaanjohtavasti suhteessa leipätekstiin) perhettä ulkopuolelta uhanneeksi "naisystäväksi". Tekijänä olleen naisen asettaminen perheen ulkopuoliseksi ja uhrina olleen miehen sen sisälle korostaa osapuolten välistä moraalista kontrastia ja tällöin naisen toiminnan moitittavuutta. Vastuu väkivallasta asettuu otsikossa tekijänä olleelle naiselle myös aktiivimuodon myötä.

Toisenlaista miesuhrin sukupuolistavaa esittämistä kuvaa puolestaan otsikko "Mies ei halunnut sairaalaan - kuoli" (IS 20.3.09). Toisin kuin useimmissa naisten puolisoilleen tekemästä väkivallasta kertovissa otsikoissa, tässä tekijän sukupuoli ja väkivaltainen toiminta on häivytetty tyystin. Otsikosta ei käy edes ilmi, että mies on ollut väkivallan uhri. Otsikon keskiössä on sen sijaan miesuhrin oma, sisukasta suomalaista maskuliinisuutta kuvastava toiminta, joka linkitetään hänen kuolemaansa. Mies on tässä otsikossa uhrinakin oman kohtalonsa herra. Osittain vastaavalla tavalla aktiiviseksi osapuoleksi on asetettu naisuhri aineiston ainoassa samaa sukupuolta olevan naispuolison tekemästä väkivallasta kertovassa otsikossa "Naispari taisteli veitset heiluen" (IL 3.12.09). Otsikko poikkeaa heterosuhteeseen sijoitettua väkivaltaa kuvaavista otsikoista korostuneen värikkään kielen ansiosta, jolla väkivallan uhkaavuus häivytetään (Syrjälä 2007). Viittaus veitsien heilumiseen luo mielikuvan tasaväkisestä tappelusta, jota leipätekstin kerronta ei tue. Kenties naisten molemminpuoliseksi mielletyllä väkivallalla on katsottu olevan enemmän viihdearvoa kuin yhden naisen toiseen kohdistamalla. Joka tapauksessa oletettavaa on, että uhrin kuvaaminen väkivaltaan osallistuvana liittyy siihen, ettei kyseessä ole vakiintuneita, sukupuolistuneita asemointeja tarjoava heteroseksuaalinen parisuhde. Tämä selittäisi myös sen, miksi kummankin osapuolen sukupuoli on mainittu.

Osapuolten suhteelle ja sukupuolelle perustuva väkivallasta kertominen toistuu myös lasten ollessa uhreja. Väkivallan tekijät on tällöin nimetty usein "isiksi" ja "äideiksi". Näiden nimeämisten sukupuolittainen eroavaisuus suhteessa väkivaltaan on ilmeistä. Äitien tekemästä väkivallasta kertominen perustuu useimmiten äitiyden ja väkivallan tekemisen vastakohtaisuudelle. Pelkistetty kerronta, kuten "Äiti löi 4-vuotiasta" (IL 2.9.09), toistuu jälleen naisten kohdalla. Yksityiskohtien liittämistä miesten väkivaltaan kuvastaa puolestaan otsikko "Humalainen isä pahoinpiteli kehitysvammaista lastaan" (IS 22.9.09). Otsikossa lapsen kehitysvammaisuus korostaa uhrin haavoittuvuutta ja maininta tekijän humalatilasta tilanteen vaarallisuutta. Vaikka leipätekstissä kerrotaan miehen sekä lapsiinsa että vaimoonsa kohdistamasta väkivallasta, mainitaan otsikossa ainoastaan haavoittuvimpana nähtävä uhri. Tällöin muiden perheenjäsenten uhriutuminen näyttäytyy vähemmän merkittävänä. Myös muut koko perheeseen kohdistuvasta väkivallasta kertovat otsikot on rakennettu yhtä lukuun ottamatta samalla tavalla. Otsikossa "Isä ripusti perheen naulakkoon" (IS 9.11.09) on puolestaan koko muun perheen uhrius esillä. Otsikko perustuu kuitenkin enemmän- 
kin teon eriskummallisuuteen kuin uhrien kokemukselle, jonka traumaattisuutta teon hassun luonteen korostaminen häivyttää. Se, että tekijään viitataan tässäkin tapauksessa sanalla "isä", kuvastaa asemointiin liittyvää sukupuolistunutta auktoriteettia ja valta-asemaa suhteessa muihin perheenjäseniin, naispuoliso mukaan lukien (vrt. Nikunen, 2006). Sanaan "äiti" ei tällaista auktoriteettioletusta liity, ja siksi samanlainen otsikko naistekijällä ei vaikuta mahdolliselta.

\section{Sukupuolten sisäinen väkivalta - sukupuoli sivuosassa}

Miesten toisiin miehiin ja naisten toisiin naisiin kohdistamasta väkivallasta kerrottaessa ei sukupuoli ole yleensä otsikoita kantavassa roolissa. Tärkeämmälle sijalle voi nousta osapuolten sijoittaminen muihin sosiaalisiin kategorioihin. Esimerkiksi naisen toiseen naiseen kohdistamasta väkivallasta kertovassa otsikossa "Lääkäri sohi PUUKOLLA professoria" (IL 7.10.09) osapuolten ammattien on ilmeisesti katsottu lisäävän uutisarvoisuutta tehokkaammin kuin heidän sukupuolensa. Myöskään esimerkiksi miehen toiseen mieheen kohdistamasta väkivallasta kertovasta otsikosta "PUOLUEPOMO YRITETTIIN MURHATA" (IS 28.10.09) eivät osapuolten sukupuolet käy ilmi. Sukupuolten sisäisestäkin väkivallasta kerrottaessa naisten sukupuoli niin tekijöinä (33 \%, N=36 vs. miehet $15 \%, \mathrm{~N}=175$ ) kuin uhreina ( $31 \%, \mathrm{~N}=36$ vs. miehet $22 \%, \mathrm{~N}=175$ ) on kuitenkin useammin esillä. Kun osapuolia kutsutaan esimerkiksi perinteisesti miehiin yhdistettyihin ammattinimikkeisiin viittaamalla, käytetään usein naisten kohdalla nais-etuliitettä, kuten "Naisrehtori hakattiin" (IS 15.10.09). Etuliitettä mies- käytetään huomattavasti harvemmin.

Miehen toiseen mieheen kohdistamasta väkivallasta kerrottaessa tuodaan lähes aina esiin epätavanomainen, kiinnostusta lisäävä teon konteksti tai tekoväline. Väkivalta tai sen osapuolet eivät siis itsessään näyttäydy kovin uutisarvoisina. Esimerkiksi otsikon "Verinen mies haki apua kaupasta" (IS 9.2.09) uutisarvo perustuu väkivallan seurausten esillä oloon julkisessa ja arkisessa kontekstissa, satunnaisten sivullisten nähtävissä. Huomio ei kiinnity ensisijaisesti siihen, mitä miehellä on tapahtunut tai kuka tekijä on. Ainoa otsikko, jossa ei tuoda esiin teon tai kontekstin yksityiskohtia, kertoo perheen sisäisestä henkirikoksesta: "Poika ampui ISÄNSÄ" (IL 26.10.09). Otsikossa omistusliite vahvistaa osapuolten kuulumisen samaan perheeseen ja korostaa isojen kirjaimien ohella teon traagisuutta.Uutisarvo perustuu siis perhesuhteelle eikä ensisijaisesti sukupuolelle. Osapuolten sukupuolelle annetun merkityksen vähäisyyttä kuvastaa myös se, että miehen toiseen mieheen kohdistamasta väkivallasta kerrottaessa esiintyy eniten koko aineistosta nollasubjekteja", kuten otsikossa "Pääsi vankilasta, yritti tappaa" (IS 22.7.09).

Osassa sukupuolten sisäisestä väkivallasta kertovissa otsikoissa sukupuoli on läsnä implisiittisesti, osana väkivaltaiselle toiminnalle annettuja merkityksiä. Miesten kohdalla väkivalta esimerkiksi liitetään usein maskuliinisiksi miellettyihin elämänalueisiin, kuten urheiluun tai ammattirikollisuuteen. Otsikossa "Suo, futis ja putka" (IS 18.7.09) intertekstuaalinen viittaus Väinö Linnan tunnettuihin sanoihin kytkee urhei- 
lun kontekstissa tapahtuneen väkivallan suomalaiseen, melankolisena ja itsetuhoisena näyttäytyvään miehuuteen. Miesten toisiin miehiin kohdistamasta väkivallasta tehdään sukupuolistuneesti ymmärrettävää myös asettamalla se heteroseksuaalisen mustasukkaisuusdraaman aiheuttamaksi. Tällä tavoin merkityksellistetyn miesten väkivallan tunnistettavuutta kuvastaa uhrin toimintaan keskittyvä otsikko, josta lukijan on helppo arvata konteksti ilman eksplikoimista: "Rakastaja pakeni kalsareissa" (IL 9.9.09). Naisten välisestä väkivallasta kertova otsikko "Raapimista ja hiustuppoja" (IS 2.11.09) tekee puolestaan naisten väkivallasta tunnistettavaa virittämällä mielikuvan seksualisoidusta "kissatappelusta". läkkäiden naisten myrkyttämisestä epäiltyjä naisia kutsutaan otsikoissa taas näennäisen sukupuolineutraalisti "insuliinihoitajiksi" (IS 2.10.09) tai "myrkkyhoitajiksi" (IL 21.4.09). Vaikka tällöin otsikot perustuvat ensisijaisesti hoitajuuden ja väkivallan väliselle kontrastille eikä väkivallan tekijän sukupuolelle, linkittyy hoitajuus ammattina mielikuvissa vahvasti naissukupuoleen.

\section{Naisiin ja lapsiin kohdistunut väkivalta perheen ulkopuolella - miestekijät marginaalissa}

Väkivallan tekijöiden sukupuoli on harvoin esillä silloin, kun tekijänä on mies ja uhrina perheen ulkopuolinen nainen tai lapsi, johon kohdistuu seksuaalista väkivaltaa. Naisten ollessa uhreja on tekijöinä olleiden miesten sukupuoli esillä vain $15 \%$ :ssa $(\mathrm{N}=89)$ otsikoista. Varsinkaan naisiin kohdistuvasta seksuaalisesta väkivallasta kertovissa otsikoissa ei yleensä painotu tekijä tai hänen toimintansa, tai jos painottuu, ei tekijästä muodostuva kuva vastaa käsitystä "tavallisista" miehistä vaan sijoittuu mies-kategorian marginaaleihin. Otsikoista ainoastaan neljässä (13\%, N=30) mainitaan tekijänä olleen miehen sukupuoli. Ainoastaan yhdessä noista tekijään viitataan sanalla "mies". Sanan "mies" yksikössä voidaan tulkita viittaavaan potentiaalisesti kaikkiin miehiin (Tainio 1999), joiden edustajana näin nimetty väkivallan tekijä nähdään. Välttämällä tuota sanaa voidaan siis välttää seksuaalisen väkivallan tekijyyden eksplisiittinen liittäminen miessukupuoleen. Tekijöitä ei myöskään ole usein nimetty väkivaltaisen toimintansa mukaisesti "raiskaajiksi". Termi mainitaan ainoastaan kahdessa, tuntemattoman miehen tekemästä seksuaalisesta väkivallasta kertovassa otsikossa. Kutsuttaessa "raiskaajaksi" seksuaalinen väkivalta määrittää tekijän identiteettiä ja korostaa teon rikosluonnetta (Mäkelä 2002). Termi ei kuitenkaan tuo tekijän sukupuolta eksplisiittisesti ilmi, minkä lisäksi se kiinnittää seksuaalisen väkivallan pikemminkin "rikollisiin" kuin "tavallisiin" miehiin. Useita raiskauksia tehneestä miehestä kertovassa otsikossa "13 UHRIA: Seksihullu vaani naisia" (IL 17.12.2009) tekijä puolestaan poikkeuksellistetaan asettamalla hänen toimintansa motiiviksi patologisen voimakas seksuaalivietti: hän ei ole kuka tahansa mies vaan "seksihullu".

Usean miehen tekemästä, naisiin kohdistuvasta seksuaalisesta väkivallasta kertovissa otsikoissa tekijöiden sukupuoli on esillä kolmessa seitsemästä, joissa poikkeuksellisesti teon kuvaus on myös aktiivissa. Näistä kaksi käsittelee prostituoituna toimivan naisen raiskaamista ryöstön yhteydessä: "Asemiehet ryöstivät ja raiskasivat 
prostituoidun" (IS 15.10.09); "Miehet ryöstivät ja raiskasivat" (IL 15.10.09). Otsikoissa seksuaaliseen väkivaltaan "ja"-sanalla rinnastettu ryöstäminen vahvistaa väkivallan tekijöiden identiteettiä rikollisina ja täten valtaväestöstä poikkeaviksi mieltyvinä. Otsikossa "Miesjoukko kävi käsiksi: opiskelijanainen raiskattiin" (IL 14.10.09) tekijöiden ja uhrin sukupuolet ovat puolestaan keskeisiä, ja niiden esittäminen korostaa väkivallan pelottavuutta ja uhrin avuttomuutta. Otsikossa tekijät muodostavat kuitenkin kasvottoman "joukon", eikä väkivaltaista toimijuutta liitetä kehenkään tiettyyn mieheen. Miesjoukon kuvataan aktiivimuotoa käyttäen ainoastaan "käyneen käsiksi", raiskauksesta kertominen on sen sijaan erotettu eri lauseeseen, jossa sitä kuvataan passiivissa ilman tekijää.

Myöskään lapsiin kohdistuvasta, perhekontekstin ulkopuolelle sijoitetusta seksuaalisesta väkivallasta kerrottaessa ei tekijöinä olleiden miesten sukupuolelle anneta painoarvoa; se ei ole eksplisiittisesti esillä yhdessäkään otsikossa $(\mathrm{N}=14)^{12}$. Tekoa ei myöskään kuvata usein aktiivimuodossa. Niin tehdään vain kahdessa otsikossa 14:stä (14 \%). Tämä eroaa selkeästi yksittäisistä, aikuisiin kohdistuvasta seksuaalisesta väkivallasta kertovista otsikoista, joissa osapuolten sukupuolet poikkeavat oletetusta ja ovat tämän ansiosta merkittävässä roolissa. Otsikossa "Mies raiskasi toisen miehen" (IL 29.9.09) kummankin osapuolen sukupuoli on yllättävä sekä heteronormatiivisuuden että seksuaalisen väkivallan sukupuolistuneisuuden valossa. Otsikossa "Naiselle raiskaussyyte, uhri yritettiin tappaa" (IS 6.8.09) selostetussa tapauksessa puolestaan vain tekijän sukupuoli poikkeaa oletuksesta ja on tuotu otsikossa esiin. Nämä "poikkeukset" vahvistavat miesten naisiin ja lapsiin kohdistaman seksuaalisen väkivallan näyttäytymistä tavanomaisena mutta myös sen näkymättömyyttä sukupuolistuneena ilmiönä.

Miesten sukupuoli ei ole yleensä esillä ( $15 \%$ :ssa otsikoista, N=27) tai keskeisessä roolissa myöskään naisiin kohdistuvien henkirikosten tekijöinä perhekontekstin ulkopuolella. Uhreina olleiden naisten sukupuoli on puolestaan korostuneen usein esillä (52\%). Muutamista tällaisista henkirikostapauksista on tehty jatkokertomuksia, joiden otsikoissa uhri tehdään tutuksi käyttämällä hänestä etunimeä (vrt. Syrjälä 2007). Usein mukana on myös kasvokuva uhrista, kuten uhrilleen tuntemattoman taksikuskin surmaamasta ja raiskaamasta nuoresta naisesta kerrottaessa. Etunimen ja kasvokuvan ansiosta uhrin sukupuoli on toistuva osa kerrontaa. Hänet tuodaan tällöin myös lähelle lukijoita, hän on kuka tahansa nuori nainen, eli kuka tahansa voisi jakaa hänen kohtalonsa. Miesuhreista ei yleensä etunimeä käytetä, minkä ansiosta he jäävät etäisemmiksi'3.

\section{Poikkeavuuden, normaaliuden ja näkymättömyyden ristivetoja}

Sukupuoli jäsentää aineistossa merkittävällä tavalla väkivaltarikosuutisten otsikoiden ilmaisua joko sen kautta, mitä niissä kerrotaan, tai sen, mitä ei kerrota. Miesten sukupuolta väkivallan tekijöinä ei tuoda ainakaan eksplisiittisesti esiin läheskään yhtä usein kuin naisten, joiden sukupuolen ympärille useat otsikot näyttävät rakentuvan. Naisten esiintyminen erityisesti henkirikosten tekijöinä on uutisoinnissa myös mää- 
rällisesti korostunutta, jos sitä verrataan rikostilastoihin. Naisten sukupuoli uhreina on niin ikään näkyvämmin esillä kuin miesten, niin otsikoissa kuin määrällisen valikoitumisen perusteella. Tämä sukupuolten erilainen näkyvyys suhteessa väkivaltaan myötäilee aikaisempien, angloamerikkalaisiin konteksteihin painottuneiden tutkimusten tuloksia (ks. Boyle 2005). Sen lisäksi, että sukupuolten ja väkivallan välisten suhteiden eroavaisuuksien voi katsoa uutisarvon kautta muovaavan näitä uutisoinnin tendenssejä, uutisarvon logiikalle pohjautuvat representaatioprosessit myös tuottavat sukupuolen ja väkivallan välistä suhdetta, vaikkakin moniulotteisilla ja osin paradoksaalisilla tavoilla. Tähän paradoksaalisuuteen heijastuu sukupuolen kaksoisluonne jo rakennettuna ja alati rakentuvana, monisyisenä valtasuhteena.

Millaista todellisuutta iltapäivälehtien väkivaltarikosuutisointi tarkalleen ottaen tuottaa ja millaisiin sukupuolta ja väkivaltaa koskeviin käsityksiin se kytkeytyy? Miesten sukupuolen suhteellinen näkymättömyys väkivallan tekijöinä kertoo, että heidän väkivaltaisesta toiminnastaan kerrottaessa on mahdollista nojautua kulttuuriseen oletukseen miehistä väkivallan tekijöinä. Naisten tekemällä väkivallalla on puolestaan enemmän uutisarvoa, jolloin se myös näyttäytyy vahvemmin sukupuolistunutta normaaliutta rikkovana. Aineistossani naisten tekemien henkirikosten uutisoinnin määrään heijastuu Ulvilan surman ja insuliinisurmien tiivis seuraaminen. Näiden tapausten uutisarvoisuus perustuu oletettavasti osaltaan tekijöiden naissukupuoleen, vaikka muutkin elementit ovat todennäköisesti vaikuttaneet niihin kohdistettuun mielenkiintoon $^{14}$. Naisten sukupuolen korostaminen väkivallan tekijöinä voi liittyä myös siihen, että naisten väkivalta on nostettu viime vuosina yhteiskunnallista keskustelua herättäväksi ilmiöksi (Lattu 2008).

Entä mitä naisuhriuden painottuminen kertoo? Toisin kuin esimerkiksi Kivivuori ym. (2002), tulkitsen tämän liittyvän iltapäivälehtien tabloidimaisuuteen, eli taipumukseen tavoitella myyntiä seksualisoiduilla väkivallan esityksillä (Karkulehto 2011, 208), enkä niinkään valveutuneisuuteen naisiin kohdistuvan väkivallan yleisyyden suhteen. Uutisoinnin keskiössä eivät ole tyypillisimmin naisten kohtaamat väkivallan muodot kuten parisuhdeväkivalta, vaan erityisesti henkirikostapaukset, joihin liittyy poikkeuksellisia piirteitä. Yksityiskohtaisemmat iltapäivälehtien otsikoiden sekä rikosuutisjuttujen (Venäläinen, tulossa) analyysit kuvastavat tämän lisäksi, kuinka naisten ja miesten esittäminen väkivallan uhreina ja tekijöinä toistaa suurelta osin sukupuolistavia asemointeja, joissa esimerkiksi vastuu väkivallasta asetetaan vahvemmin naisille kuin miehille. Tämän voi katsoa pikemminkin ylläpitävän väkivallan sukupuoliasetelmaa kuin tuovan siihen muutosta. Naisuhriuden korostunut esittäminen iltapäivälehtien tyyliin voi myös yhdistyä naisten kokemaan väkivallan pelkoon ja sen myötä heidän liikkumatilansa rajoittumiseen (ks. Naylor 2001). Lukiessaan päivittäisiä uutisia kenen tahansa tavallisen naisen kohtaamasta väkivallasta naiset voivat sisäistää heidän sukupuoleensa liitetyn mahdollisuuden joutua väkivallan uhriksi ja kokea olonsa turvattomiksi. Sukupuolta valtasuhteena voi siis tuottaa myös se, että naissukupuoli, uhrius ja turvattomuus sidotaan toistuvasti yhteen.

Kun naisuhrien näkyvyys painottuu, näyttäytyvät väkivallan tekijöinä olleiden miesten sukupuoli ja väkivaltainen toiminta toissijaisina erityisesti seksuaalisesta 
väkivallasta kerrottaessa. Tekijän sukupuolen näkymättömiin tai sivuosaan jättäminen viestittää, ettei se ole huomionarvoinen seikka tietyntyyppisestä väkivallasta puhuttaessa. Tällainen esittäminen tukee seksuaalisen väkivallan ja miesten välisen sidoksen näyttäytymistä luonnollisena vaikkakin vaiettuna sen sijaan, että se yhdistettäisiin naisten ja miesten välistä suhteutumista niin materiaalisesti kuin representaatiomaisesti järjestävään sukupuoleen. Voi siis katsoa, että tällöin suositaan näennäisen sukupuolineutraalia puhetapaa, jossa seksuaalista väkivaltaa ei sen sukupuolistuneisuudesta huolimatta nähdä sukupuolistavaan sosiaaliseen järjestykseen liittyvänä ongelmana (vrt. Ronkainen \& Näre 2008).

Sukupuolikäsitykset linkittyvät niin ikään siihen, ettei miehiä esiinny usein uhreina rikosuutisissa, varsinkaan miehiksi otsikoissa kutsuttuina. Maskuliinisuutta, johon sisältyy oletus potentiaalisesta väkivallan tekijyydestä (ks. Jokinen 2000), on vaikea sovittaa yhteen kulttuurisesti voimattomuutta merkitsevän uhriuden kanssa. Miesten uhriudelle sekä miesten väliselle väkivallalle annetun huomion vähäisyys ylläpitää asetelmaa, jossa väkivalta nähdään normaalina miesten elämään kuuluvana ilmiönä. Kun miesten sukupuolta ei väkivallan tekijöinäkään tuoda usein esiin, voi väkivalta miesten tekemänä ja kokemana näyttäytyä sukupuolettomana väkivallan normina (vrt. Boyle 2005), jota ei nähdä tarpeelliseksi selittää sukupuolisensitiivisesti. Miesuhrit mielletään tällöin liiankin normaaleiksi, jolloin paradoksaalisesti he ja heihin kohdistuva väkivalta osana väkivallan normaalistettua sukupuolistuneisuutta jää iltapäivälehdissä näkymättömiin.

Cynthia Carter (1998) on kuvannut, kuinka myös poikkeavaksi mielletty väkivalta voi mediaesityksissä toistuessaan normalisoitua, jolloin se aletaan mieltää tavanomaiseksi ja vähemmän järkyttäväksi. Erityisesti sensaatiohakuiset uutislehdet joutuvat tämän ansiosta etsimään yhä erikoisempia väkivaltatapauksia, joita nostaa otsikoihinsa lehtiä myydäkseen. Taka-alalle painuvat rutiinitapaukset mieltyvät näitä vasten niin tavallisiksi, ettei niitä enää huomata (emt.). Onkin syytä pohtia, mitä tämä voi merkitä suomalaisessa kontekstissa. Normalisoituuko ajan mittaan naisten kokema väkivalta, jos sen suhteellisesti korostunut, uhrien sukupuolen esiin tuova uutisoiminen toistuu? Entä alammeko naisten tekijyyden korostuessa liittää väkivaltaisuuden kaikkiin naisiin, vai kenties ainoastaan joihinkin poikkeaviksi nähtyihin, jolloin "normaali" naiseus voidaan yhä mieltää väkivallattomaksi vastakohdaksi miehuudelle (ks. Chesney-Lind 2006)?

Iltapäivälehdet ovat vain pieni osa yhä pirstaloituneempaa ja laajempaa mediakenttää (ks. Seppänen \& Väliverronen 2012). Ne ovat silti usealle yhä osa päivittäistä elämää, jonka mediatulva vaikuttaa siihen, millaisia käsityksiä inmisille syntyy. Erityisesti näin on todettu olevan niiden aihealueiden kohdalla, joista ei omakohtaista kokemusta ole (Mustonen 2001, 63). Lukijat eivät tietenkään ota vain passiivisesti vastaan mediassa sanottua, vaan voivat suhtautua mediateksteihin kritisoiden ja vallitsevista merkityksistä poikkeavia tulkintoja luoden. Muun muassa etnometodologisen näkökulman mukaan kulttuuristen ymmärrysten ja käytäntöjen toistuvuus ja luonnollistuminen perustuvat kuitenkin suurelta osin tiedostamattomiin toiminnallisiin prosesseihin. Tämän vuoksi jaettua ymmärrystämme tuottavien prosessien näkyväksi tekeminen voi edesauttaa mediatekstien kriittisen lukutavan laajenemista. 
Oman tietämisensä sosiokulttuuristen sidosten ja seurausten reflektoiminen on tärkeää myös toimittajille. Väkivallan esittämisellä mediassa voi olla myönteisiä seurauksia siihen puuttumisen kannalta (Karkulehto 2011, 208-209). Tavoilla, joilla se tehdään, on kuitenkin merkitystä sen suhteen, millaisia tulkintamahdollisuuksia lukijoille avautuu. Myyntipaineiden alaisinakin rikosuutisesityksiä tuottavat toimittajat tekevät aina valintoja. Valintojen tekijöinä he ovat osaltaan vastuussa siitä, kuinka he esityksissään todellisuutta toistavat (vrt. emt., 236). Jos tieto ja ne symbolit, joita hyödyntämällä sitä välitämme ja luomme, eivät ole ikinä täysin viattomia tai neutraaleja, nousee relevantiksi kuitenkin toimittajien tekemien valintojen lisäksi myös kysymys siitä, miksi tiedämme ja puhumme kulttuurimme sisällä väkivallasta ja sukupuolesta tietyillä tavoilla.

\section{Viitteet}

1 Suomalaisia iltapäivälehtiä on luonnehdittu vakaviksi populaarilehdiksi. Niiden keskeisenä toimintaperiaatteena on uutisten välittäminen, vaikka ne tyyliltään perustuvatkin suurelta osin viihteellisyyteen ja ns. tabloidimaisuuteen (Herkman 2005, 288-289).

2 Artikkeli pohjautuu meneillään olevaan naisia väkivallan tekijöinä tarkastelevaan väitöskirjatutkimukseeni, jossa aineistona ovat myös iltapäivälehtien naisten tekemästä väkivallasta kertovat rikosuutisjutut vuosilta 2010-2011.

3 Bronwyn Naylorin (2001) mukaan myös miehiin kohdistuvan väkivallan uutisoinnissa korostuu satunnainen, tuntemattomien tekemä väkivalta. Kuten Karen Boyle $(2005,60)$ on tuonut esiin, miesten uhriutuminen on kuitenkin jäänyt kriittisessä mediatutkimuksessa vähälle huomiolle.

$4 \quad$ Ilta-Sanomien levikki vuonna 2012 oli 132253 ja Iltalehden 91219 (Levikintarkastus 2012).

5 Rikosuutisjutuksi olen määritellyt itsenäisen tekstikokonaisuuden, jolla on pääotsikko. Yhdessä lehden numerossa voi olla useita samaa rikosta käsitteleviä juttuja, ja samaa rikosta voidaan käsitellä useassa lehden numerossa.

6 Jos saman teon/tekojen tekemiseen osallistui nainen ja mies, on väkivalta luokiteltu heidän yhdessä tekemäkseen. Kuudessa jutussa puolestaan kerrottiin sekä miehen että naisen erikseen tekemästä väkivallasta, jotka on laskettu sekä miehiin että naisiin.

7 Alaikäisten tekemästä väkivallasta kertovat jutut, joita oli miesten tekeminä 31 ja naisten tekeminä 4, on jätetty tässä vaiheessa pois.

8 Nämä prosenttiluvut on laskettu kokonaismäärästä, jossa ei ole mukana samanaikaisesti naisiin ja miehiin tai uhreihin, joiden sukupuoli ei ole tiedossa, kohdistunut väkivalta.

9 Analyysissa ovat mukana ainoastaan juttujen pääotsikot. Alaotsikoiden, jotka on usein sijoitettu erilleen pääotsikosta ja jotka voivat sisältää useita virkkeitä, olen katsonut muodostavan oman erillisen kokonaisuutensa, minkä vuoksi ne eivät sisälly analyysiin. Otsikkoanalyysissa eivät ole mukana väkivallalla uhkaamisesta, naisten ja miesten yhdessä tekemästä tai naisiin sekä miehiin kohdistuvasta väkivallasta kertovat jutut eivätkä ne, joista ei käy uhrin sukupuoli ilmi. Näitä rajauksia perustelee keskittyminen osapuolten sukupuolen merkitykseen otsikoiden muotoutumisen kannalta.

10 Sanasta "mies", toisin kuin sanasta "vaimo", ei pysty päättelemään, milloin henkilö sidotaan osaksi parisuhdetta (ks. Tainio 1999). Tämä hankaloittaa sen vertaamista, milloin osapuolet esitetään parisuhteen osapuolina ja milloin yksilöllisinä toimijoina. Otsikoissa, joissa ilmenee sekä sana "mies" että "vaimo", osapuolten suhde tuodaan kuitenkin usein ilmi jommankumman sanan perään liitetyllä omistusliitteellä.

11 Kun toimintaa kuvataan aktiivissa, mutta lauseessa ei ilmene subjektia, puhutaan nollasubjektista (Tainio 1999). Miesten tekemää väkivaltaa käsittelevissä otsikoissa nollasubjekti on aineistossa yleisempi (yhdeksän otsikkoa) kuin naisten (kaksi otsikkoa). Nollasubjektia esiintyy useimmiten pienten artikkeleiden otsikoissa, jolloin sen käyttöä todennäköisesti motivoi taloudellisuusperiaate, eli se liittyy artikkelille varatun tilan rajallisuuteen. 
12 Kaikki lapsiin kohdistuvasta seksuaalisesta väkivallasta kertovat, analyysiin sisältyvät otsikot käsittelevät miesten tekemää väkivaltaa.

13 Myöskään esimerkiksi henkirikoksista epäiltyihin naisiin ei viitata otsikoissa tai leipätekstissäkään etunimellä. Tämä tekee heistä etäisempiä ja sukupuolettomampia, heihin ei siis kytketä feminiinisyyttä naisetunimen myötä.

14 Ulvilan surmaa oli käsitelty mediassa laajasti jo ennen vuoden 2009 yllätyskäännettä, jolloin epäillyksi paljastettiin miesuhrin vaimo. Insuliinisurmien saama huomio kytkeytyy puolestaan yhteiskunnalliseen huoleen hoiva-alan tilasta ja hoivasuhteeseen sijoittuvan väkivallan järkyttävyyteen.

\section{Kirjallisuus}

Berrington, Eileen \& Honkatukia, Päivi (2002). An evil monster and a poor thing: Female violence in the media. Journal of Scandinavian studies in criminology and crime prevention 3: 1, 50-72.

Boyle, Karen (2005). Media and violence: Gendering the debates. Lontoo: SAGE.

Carter, Cynthia (1998). When the 'extraordinary' becomes 'ordinary'. Teoksessa: Carter, Cynthia; Branston, Gill \& Allan, Stuart (toim.). News, gender and power. Lontoo: Routledge, 219-232.

Chesney-Lind, Meda (2006). Patriarchy, crime, and justice: Feminist criminology in an era of backlash. Feminist criminology 1: 1, 6-26.

de Lauretis, Theresa (1987). Technologies of gender: Essays on theory, film, and fiction. Lontoo: Macmillan.

Erickson, Richard; Baranek, Patricia \& Chan, Janet (1987). Visualizing deviance: A study of news organization. Milton Keynes: Open University.

Fairclough, Norman (1997). Miten media puhuu. Tampere: Vastapaino.

Foucault, Michel (1972). The archeology of knowledge. Lontoo: Tavistock.

Foucault, Michel (1976). The history of sexuality: volume 1: An Introduction. Harmondsworth: Penguin.

Frazer, Alexandra \& Miller, Michelle (2009). Double standards in sentence structure: Passive voice in narratives describing domestic violence. Journal of language and social psychology 28: 1, 62-71.

Garfinkel, Harold (1984 [1967]). Studies in ethnomethodology. Cambridge: Polity.

Gruenewald, Jeff; Pizarro, Jesenia \& Chermak, Steven (2009). Race, gender, and the newsworthiness of homicide incidents. Journal of criminal justice 37: 3, 262-272.

Hall, Stuart (1997). The work of representation. Teoksessa: Hall, Stuart (toim.). Representation: cultural representations and signifying practices. Milton Keynes: The Open University, 13-64.

Halliday, M.A.K. (1978). Language as social semiotic: The social interpretation of language and meaning. Lontoo: Edward Arnold.

Hemánus, Pertti (1966). Helsingin sanomalehtien rikosaineisto: Tutkimus rikosaineiston funktionaalisesti merkitsevistä piirteistä ja niihin vaikuttavista tekijöistä. Tampere: Tampereen yliopisto.

Herkman, Juha (2005). Kaupallisen television ja iltapäivälehtien avoliitto: Median markkinoituminen ja televisioituminen. Tampere: Vastapaino.

Jewkes, Yvonne (2004). Media and crime. Lontoo: SAGE.

Jokinen, Arto (2000). Panssaroitu maskuliinisuus: Mies, väkivalta ja kulttuuri. Tampere: Tampere University Press.

Kantola, Johanna; Norocel, Christian \& Repo, Jemima (2011). Gendering violence in the school shootings in Finland. European journal of women's studies 18: 2, 183-197.

Karkulehto, Sanna (2011). Seksin mediamarkkinat. Helsinki: Gaudeamus.

Kivivuori, Janne; Kemppi, Sari \& Smolej, Mirka (2002). Etusivujen väkivalta: Väkivalta iltapäivälehtien etusivuilla, todellisuudessa ja ihmisten peloissa 1980-200o. Helsinki: Oikeuspoliittinen tutkimuslaitos.

Lattu, Emmi (2008). Naisten tekemä väkivalta. Teoksessa: Näre, Sari \& Ronkainen, Suvi (toim.). Paljastettu Intiimi. Sukupuolistuneen väkivallan dynamiikka. Rovaniemi: Lapin yliopistokustannus, 168-189.

Lazar, Michelle (toim.) (2005). Feminist critical discourse analysis: gender, power and ideology in discourse. Basingstoke: Palgrave Macmillan.

Levikintarkastus 2012. Saatavilla: http://www.levikintarkastus.fi/levikintarkastus/tilastot.php. (luettu 4.9.2013). 
Meloy, Michelle \& Miller, Susan (2009). Words that wound: Print media's presentation of gendered violence. Teoksessa: Humphries, Drew (toim.). Women, violence, and the media: Readings in feminist criminology. Boston: Northeastern University Press, 29-56.

Mustonen, Anu (2001). Mediapsykologia. Helsinki: WsOY.

Mäkelä, Anna (2002). "Älä lähde yksin humalassa hoipertelemaan.": Raiskaus uutisena Helsingin Sanomissa 1996-1999. Helsinki: Stakes.

Mäkelä, Anna; Puustinen, Liina \& Ruoho, liris (toim.) (2006). Sukupuolishow: Johdatus feministiseen mediatutkimukseen. Helsinki: Gaudeamus.

Mäkipää, Leena \& Mörä, Tuomo (2009). Henkirikos yhdistää. Teoksessa: Väliverronen, Esa (toim.). Journalismi murroksessa. Helsinki: Gaudeamus Helsinki University Press, 207-221.

Naylor, Bronwyn (2001). Reporting violence in the British print media: Gendered stories. The Howard journal 40: 2, 180-194.

Nikunen, Minna (2005). Surman jälkeen itsemurha: Kulttuuriset luokitukset rikosuutisissa. Tampere: Tampere University Press.

Nikunen, Minna (2006). Parenthood in murder-suicide news: Idealized fathers and murderous mums. Journal of Scandinavian studies in criminology and crime prevention 7: 2, 164-184.

Nikunen, Minna (2011). Murder-suicide in the news: Doing the routine and the drama. European journal of cultural studies 14: 1, 81-101.

Ronkainen, Suvi (2004). Kvantitatiivisuus, tulkinnallisuus ja feministinen tutkimus. Teoksessa: Liljeström, Marianne (toim.). Feministinen tietäminen: Keskustelua metodologiasta. Tampere: Vastapaino, 44-69.

Ronkainen, Suvi \& Näre, Sari (2008). Intiimin haavoittava valta. Teoksessa: Näre, Sari \& Ronkainen, Suvi (toim.). Paljastettu Intiimi: Sukupuolistuneen väkivallan dynamiikka. Rovaniemi: Lapin yliopistokustannus, 7-40.

Seppänen, Janne \& Väliverronen, Esa (2012). Mediayhteiskunta. Tampere: Vastapaino.

Sipilä, Noora \& Honkatukia, Päivi (2010). Naiset rikoksen tekijöinä ja uhreina. Teoksessa: Rikollisuustilanne 2009: Rikollisuus ja seuraamusjärjestelmä tutkimusten valossa. Helsinki: Oikeuspoliittinen tutkimuslaitos, 253-269.

Smolej, Mirka (2011). News media, crime and fear of violence. Helsinki: Oikeuspoliittisen tutkimuslaitoksen tutkimuksia.

Syrjälä, Hanna (2007). Väkivalta lööppijulkisuudessa. Journalismin tutkimusyksikkö. Tiedotusopin laitos. Tampere: Tampereen yliopisto.

Tainio, Liisa (1999). Opaskirjojen kieli ikkunana suomalaiseen parisuhteeseen. Naistutkimus 12: 1, 2-26.

Valtonen, Sanna (1998). Hyvä, paha media: Diskurssianalyysi kriittisen mediatutkimuksen menetelmänä. Teoksessa: Kantola, Anu; Moring, Inka \& Väliverronen, Esa (toim.). Media-analyysi: Tekstistä tulkintaan. Lahti: Helsingin yliopiston Lahden tutkimus- ja koulutuskeskus, 93-121.

van Zoonen, Liesbet (1994). Feminist media studies. Lontoo: SAGE.

Venäläinen, Satu (julkaisematon käsikirjoitus). Violence, gender and social categorizations in media texts (työnimi).

Väliverronen, Esa (2009). Journalismi kriisissä? Teoksessa: Väliverronen, Esa (toim.). Journalismi murroksessa. Helsinki: Gaudeamus Helsinki University Press, 13-31.

West, Candace \& Zimmerman, Don (1987). Doing gender. Gender and society 1: 2, 125-151. 